NOTES AND COMMENTS

\title{
GLASSY MICROSPHERULES FROM BOMB COMBUSTION OF CHARCOAL
}

\author{
RICHARD BURLEIGH and NIGEL MEEKS
}

Research Laboratory, The British Museum, London WC1B 3DG, England

Glassy microspherules, typically $200 \mu \mathrm{m}$ or less in diameter, are well documented from a variety of terrestrial and extraterrestrial sources (Baker, 1959, p 192-198; Glass, 1969; Rost, 1969; McKay, Greenwood \& Morrison, 1970; Mueller \& Hinsch, 1970; Cross, 1971; O’Keefe, 1980). To these we would add the formation of microspherules of similar habit when wood charcoal is burned in a combustion bomb (Barker, Burleigh \& Meeks, 1969; Burleigh, 1973, 1974; Switsur, 1973; Switsur et al, 1974) as a first step in the chemical synthesis of samples for ${ }^{14} \mathrm{C}$ age measurement. The glassy material of these spherules originates from fusion at the high temperatures reached during the combustion, of traces of alkali-metal minerals in the charcoal and silica bodies (phytoliths) within its microstructure. Other materials commonly burned, such as bone collagen, do not yield microspherules. The age and source of the charcoal are immaterial, though different species (and perhaps other woody plant materials) may be moreor-less productive of spherules. Here we give a brief summary of the characteristics of these glassy microspherules, based on optical and scanning electron microscopy and energy-dispersive x-ray analysis.

Most of the microspherules from any one combustion range in size from 0.15 to $1.5 \mathrm{~mm}(150-1500 \mu \mathrm{m})$, are generally either brown or green, and may be either clear or opaque. Some are of mixed color with swirling patterns clearly visible in polished cross-section. Aggregates do occur, but most are individual spherules and close to true spheres in form. Many incorporate gas vesicles and, in one extreme instance, the glass formed only a thin envelope or cenosphere surrounding a single gas bubble. Some spherules incorporate mineral (quartz) grains, probably derived from the deposits from which the charcoal originated. Within some spherules are dendritic structures representing metallic inclusions derived from the molten combustion filament.

Chemically the microspherules fall into two broad groups having either high sodium (typically $23 \% \mathrm{Na}_{2} \mathrm{O}, 12 \% \mathrm{Al}_{2} \mathrm{O}_{3}, 53 \% \mathrm{SiO}_{2}, 1.5 \% \mathrm{~K}_{2} \mathrm{O}$, $2.5 \% \mathrm{CaO}, 8 \% \mathrm{Fe}_{2} \mathrm{O}_{3}$ ) or high calcium content (typically $28 \% \mathrm{CaO}, 11 \%$ $\mathrm{Al}_{2} \mathrm{O}_{3}, 52 \% \mathrm{SiO}_{2}, 2 \% \mathrm{~K}_{2} \mathrm{O}, 7 \% \mathrm{Fe}_{2} \mathrm{O}_{3}$ ). Their colors result mainly from the presence of iron oxides and other metallic ions in various states of reduction, and both groups may be either green or brown. Variations in composition occur within spherules from a single combustion and also within the different phases of a single spherule. The differences are attributable both to variations in composition of the minor constituents of the charcoal sample, and the rapidity of the fusion cycle in a typical combustion in which the spherules begin to solidify before uniform mixing of the glass and mineral species can take place. Measurements of softening temperatures showed 
that the high-sodium spherules begin to soften at $800^{\circ} \mathrm{C}$ and the highcalcium spherules at temperatures in excess of $1000^{\circ} \mathrm{C}$. The typical calcareous composition, if considered as a ternary system, $\mathrm{Al}_{2} \mathrm{O}_{3}-\mathrm{SiO}_{2}-\mathrm{CaO}$, falls within the anorthite region with a melting point of ca $1400^{\circ} \mathrm{C}$ (Muan \& Osborn, 1965, p 95), and there are data to suggest that for a melt of this composition with a very low viscosity and a high fluidity of ca 1 poise, a temperature of $1600-1800^{\circ} \mathrm{C}$ would be in order (Bottinga \& Weill, 1972). The consistently regular form of the spherules and their prominent convection flow lines suggest, however, that during the cycle of their formation much higher temperatures, possibly up to $2000^{\circ} \mathrm{C}$ or greater, may have been reached in the oxygen atmosphere (Bodsworth, 1963, p 134; Wheeler, 1958, p 39). This would allow great fluidity of the melt and rapid spherulization to occur.

From this observation, the general inference can be drawn that the property uniting all the very different processes, whether lunar, terrestrial, or artificial, by which microspherules are formed, is the tendency (given the constituents for the formation of a glass and temperatures well above its melting point) for rapid coalescence of discrete droplets under surface tension alone, in contrast with the formation of an amorphous mass that would be characteristic of slower processes, lower temperatures and less energetic conditions.

\section{ACKNOWLEDGMENT}

We wish to thank Professor Rudolf Rost, Department of Geochemistry, Mineralogy and Crystallography, Charles University, Prague, Czechoslovakia, for helpful advice.

\section{REFERENCES}

Baker, G, 1959, Tektites: Natl Mus Victoria Mem, no. 23 (Melbourne).

Barker, H, Burleigh, R and Meeks, N, 1969, New method for the combustion of samples for radiocarbon dating: Nature, v 221 , p 49-50.

Bodsworth, C, 1963, Physical chemistry of iron and steel manufacture: London, Longmans.

Bottinga, Y and Weill, D, 1972, The viscosity of magmatic silicate liquids-a model for calculation: Am Jour Sci, v 272, p 442-443.

Burleigh, R, 1973, Bomb combustion of radiocarbon samples, in Rafter, T A and Grant-Taylor, T, eds, Internatl conf on radiocarbon dating, 8th, Proc: Wellington, New Zealand, Royal Soc New Zealand, v 1, p 110-119.

_ 1974, A bomb method for rapid combustion of samples, in Crook, M A and Johnson, P, eds, Liquid scintillation counting, v 3, p 295-302: London, Heyden.

Cross, C A, 1971, Formation of glass spheres on the moon: Nature, v 233, p 185-186.

Glass, B P, 1969, Silicate spherules from Tunguska impact area--electron microprobe analysis: Science, v 164, p 547-549.

McKay, D S, Greenwood, W R and Morrison, D A, 1970, Morphology and related chemistry of small lunar particles from Tranquility Base: Science, v 167, p 654-656.

Muan, A and Osborn, E F, 1965, Phase equilibria among oxides in steelmaking: Oxford, Pergamon.

Mueller, G and Hinsch, G W, 1970, Glassy particles in lunar fines: Nature, v 228, p 254258.

O'Keefe, J A, 1980, The terminal Eocene event-formation of a ring system around the Earth?: Nature, v 285, p 309-311.

Rost, R, 1969, Sculpturing of moldavites and the problem of micromoldavites: Jour Geophys Research, v 74, p 6816-6824.

Switsur, V R, 1973, Combustion bombs for radiocarbon dating, in Rafter, T A and GrantTaylor, T, eds, Internatl conf on radiocarbon dating, 8th, Proc: Wellington, New Zealand, Royal Soc New Zealand, v 1, p 120-132.

Switsur, V R, Burleigh, R, Meeks, N and Cleland, J M, 1974, A new sample combustion bomb for radiocarbon dating: Internatl Jour Applied Radiation and Isotopes, v 25, p $113-$ 117.

Wheeler, E L, 1958, Scientific glassblowing: New York, Interscience. 